Ciprian NIT⿱⿴囗十⺝ ESCU

\title{
LOCUL MINISTERULUI AFACERILOR EXTERNE ÎN SISTEMUL INSTITUȚIONAL AL ROMÂNIEI (1948 - 1989)
}

\author{
THE PLACE OF THE MINISTRY OF FOREIGN AFFAIRS IN ROMANIA'S \\ INSTITUTIONAL SYSTEM (1948-1989)
}

\begin{abstract}
This paper aims to clarify the role played by several institutions in the elaboration and coordination of communist Romania's foreign policy. The author pays special attention to the Ministry of Foreign Affairs and highlights its particular role within the institutional system and its relations with other state structures during the communist period.
\end{abstract}

Keywords: Romanian Communist Party; Romania; Ministry of Foreign Affairs; diplomacy

Ministerul Afacerilor Externe al României, încă de la crearea sa în secolul XIX, a reprezentat guvernul în relaţiile sale internaţionale, înfăptuind politica externă a țării pe baza liniei generale a acestei politici, trasată de către conducerea superioară a Statului. Privind retrospectiv prima jumătate a secolului XX, în privința locului MAE în cadrul sistemului instituțional al României în perioada imediat următoare de după Marea Unire de la 1918, considerăm sugestivă afirmația în Senat la 4 iulie 1921 a omului politic Take Ionescu, ministru de Externe la acea dată: „Am ajuns d-lor, la această convingere, că după război, în afară de ministerul care privește forţa publică, cel mai important departament, din punct de vedere al acțiunii Statului, este Ministerul de Externe. Timp de 10-15 ani de aici înainte va fi tot așa. Așa încât ceea ce trecea drept sinecură, drept un fel de cenușăreasă în serviciile publice, astăzi în urma războiului este principalul"'1. Peste ani, în 1944, MAE deținea

\footnotetext{
* Consiliul Național pentru Studierea Arhivelor Securității, București; cnitulescu@yahoo.com.

1 Organizarea instituțională a Ministerului Afacerilor Externe. Acte și documente, vol. 2 (1920-1947), București, Fundația Europeană Titulescu, 2006, p. 53. Take Ionescu menționa cu acel prilej că ,,dacă aș compara numai numărul hârtiilor care ies acum, vă pot spune că într-o lună ies mai multe hârtii decât înainte de război în doi ani. O depeșă de la o legațiune a
}

Analele Universităţii „Dunărea de Jos” din Galaţi, Seria 19, Istorie, tom XVIII, 2019, pp. 135146. 
în continuare un loc însemnat în cadrul sistemului instituțional al României, așa cum rezultă dintr-un raport al lui Mihai Antonescu (vicepreședinte al Consiliului de Miniștri și ministru de Externe) către mareșalul Ion Antonescu din 20 martie 1944, în care ținea să sublinieze că „Statul trăiește prin calitatea sa de putere publică de sine stătătoare, dar și prin personalitatea și funcțiunile sale internaționale. [subl. ns.] (...) Ministerul Regal al Afacerilor Străine exercită un drept de absorbire a tuturor activităților internaționale ale statului (...) i-am unit toate serviciile, a căror activitate internațională, fie pe plan politic, fie pe plan economic și de interese private, fie pe plan cultural și de presă, era până azi împărțită cu alte departamente, cu acela al Economiei Naționale sau acela al Propagandei."

În rândurile de mai jos ne-am propus să prezentăm instituțiile României comuniste care au fost implicate constituțional în politica externă a țării, date despre structurile organizației Tratatului de la Varşovia cu rol de a stabili poziția generală internațională a țărilor comuniste din Europa, într-o epocă a Războiului Rece, reglementările care stăteau la baza colaborării la oficiile diplomatice ale țării între MAE și alte ministere, precum Ministerul de Interne, Ministerul Apărării Naționale și Ministerul Comerțului Exterior, informații în cifre privind rezultatul politicii externe a României la momentul său de vârf (rod al colaborării între diverse instituții), dar și câteva fragmente din însemnări ale unor diplomați importanți, ce reflectă și locul MAE în sistemul instituțional și decizional în diverse etape ale epocii comuniste, inclusiv despre impactul aşa-zisei Declaraţii de independență a PMR din aprilie 1964, anii '60 având de altfel o importanță deosebită pentru politica externă a României și pentru politica internațională.

În perioada comunistă, instituțiile cu atribuții în politica externă a țării erau Marea Adunare Națională și Consiliul de Stat, Guvernul (intitulat până în martie 1974 Consiliul de Miniștri) și Ministerul Afacerilor Externe, dar şi Comitetul Central al P.C.R.

Marea Adunare Națională stabilea linia generală a politicii externe a țării, aşa cum prevedea articolul 43 al Constituției din 21 august 1965. În cadrul acesteia exista și o Comisie permanentă de Afaceri Externe (cu rol de a prezenta rapoarte la proiecte de legi, precum cele pentru ratificarea unor Tratate, dar și de a înainta unele

noastră, înainte de război era un eveniment, astăzi aproape nu trece zi în care să nu sosească 10-15 depeșe și 20-30 să nu plece de la minister".

2 Ibidem, pp. 254- 256. Mihai Antonescu preciza atunci că „deși ultima lege de organizare a Ministerului Afacerilor Străine este din 17 februarie 1939 și urma legii din 18 iulie 1921, totuși în realitate, legea Ministerului Afacerilor Străine era vechea lege din 1873 (...) Aceste legi nu făceau însă decât să împartă administrația Ministerului Afacerilor Străine în administrație centrală și servicii exterioare, (...) agenții consulari fiind simpli funcționari administrativi, agenții economici neexistând în aceste legi, deși funcțiunile economice internaționale ale statului sunt esențiale, iar personalul de presă fiind de-abia menționat." 
inițiative legislative). Chiar în epoca stalinistă era una din cele 8 Comisii permanente ale M.Ad.N. din 1948, reduse apoi, fiind una din cele 3 Comisii permanente ${ }^{3}$ (formate din 11-13 deputați) din 1953, alături de Comisia de propuneri legislative și de Comisia bugetară. Un moment important 1-a constituit Declarația Marii Adunări Naționale a Republicii Socialiste România cu privire la principiile de bază ale politicii externe a României $i^{4}$, adoptată în ședință extraordinară la 22 august 1968, ca urmare a invadării Cehoslovaciei de către armatele a cinci state membre ale Tratatului de la Varșovia.

Consiliul de Stat (creat în martie 1961, format dintr-un președinte, 3 vicepreședinţi și 15 membri, continuator al Prezidiului M.Ad.N. şi anterior al Prezidiului R.P.R., înființat la rândul său în ziua abdicării regelui Mihai) era subordonat M.Ad.N., cu atribuții exercitate în mod permanent și atribuții exercitate numai între sesiunile Marii Adunări Naţionale. Printre atribuțiile permanente ale Consiliului de Stat, menționate în articolul 63 al Constituţiei din 1965, existau și cele legate de politica externă a României: ratificarea și denunțarea tratatelor internaționale, cu excepția acelora a căror ratificare sau denunțare era de competența M.Ad.N.; stabilirea rangurilor misiunilor diplomatice; acreditarea şi rechemarea reprezentanților diplomatici ai R.S.R.; primirea scrisorilor de acreditare şi de rechemare a reprezentanților diplomatici ai altor state. În relațiile cu alte state, Consiliul de Stat, prin președintele său, reprezenta România ${ }^{5}$. Intre sesiunile M.Ad.N., Consiliul de Stat devenea organul suprem al puterii de stat. Înființarea în 1974 a instituției Președintelui Republicii a redus atribuțiile sale.

Consiliul de Miniștri, potrivit Legii nr. 24/ 17 decembrie 1969, reprezenta organul suprem al administrației de stat, era ales de Marea Adunare Naţională, își desfăşura activitatea potrivit principiului conducerii colective (fiecare minister fiind condus de un Colegiu, care hotăra în problemele generale privind activitatea ministerului), fiecare membru al guvernului fiind răspunzător atât pentru propria sa activitate, cât și pentru întreaga activitate a Consiliului de Miniștri, în intervalul dintre sesiunile M. Ad. N. aceștia fiind răspunzători în fața Consiliului de Stat. Consiliul de Miniștri stabilea și măsuri generale pentru aducerea la îndeplinire a

\footnotetext{
${ }^{3}$ Dr. Florin Vasilescu, Comisiile parlamentare. Realități și perspective, București, Ed. Științifică și Enciclopedică, 1982, pp. 224, 227. Potrivit Legii nr. 1/1969 se extindea aria atribuțiilor acestor Comisii permanente: primeau sarcina de a examina și dezbate orice proiecte de legi, decrete, hotărâri sau acte ce urmau a fi adoptate, fie de către Marea Adunare Națională, fie de către Consiliul de Stat. (op. cit., p. 254)

${ }^{4}$ Principiile de bază ale politicii externe a României, Ed. Politică, 1968, pp. 25-38. Sesiunea extraordinară a M.Ad.N. a avut loc a doua zi după ședința comună a CC al PCR, a Consiliului de Stat și a Guvernului RSR.

${ }^{5}$ Mircea Lepădătescu, Sistemul organelor statului in Republica Socialistă, București, Ed. Științifică, 1966, p. 203.
} 
politicii externe, exercitând conducerea generală în domeniul relațiilor cu alte state și luând măsuri pentru încheierea acordurilor internaționale. Articolul 11 preciza că președintele Consiliului de Miniștri reprezenta guvernul în relațiile internaționale. Diplomatul și profesorul universitar Aurel Preda considera, într-o lucrare publicată în anul 2007, că ,în ultimii 50 ani, activitatea diplomatică a șefilor de state și de guvern a crescut substanțial."

Partidul Comunist Român (în anii 1948-1965 denumit Partidul Muncitoresc Român) reprezenta forul conducător al politicii externe românești în anii 1948-1989. Deși Comitetul Central conducea întreaga activitate a partidului în intervalul dintre Congrese, asigurând înfăptuirea rolului conducător al partidului în toate domeniile de activitate, inclusiv în politica externă, deciziile se luau în cadrul unui organ executiv al C.C., intitulat Secretariat în epoca Gheorghiu-Dej, Prezidiul Permanent în anii1965-1974 și Biroul Permanent al C.P.Ex. în anii 1974-1989. Numărul membrilor Secretariatului Comitetului Central a variat, de la 4- 5 membri în anii 1944-1960 (în timp ce Biroul Politic, care conducea partidul între Plenarele C.C., avea atunci 7-18 membri), 4 în anii 1960-1965 și între 7-10 în anii 1965-19897. În primii ani ai RPR, în cadrul Secretariatului, Iosif Chişinevschi (nume iniţial Roitman) a fost cel desemnat să coordoneze activitatea externă. Astfel, în ședința Biroului Politic al CC al PMR din 14 mai 1948 Chișinevschi a fost desemnat să conducă Secția Politicii Externe (în timp de Ana Pauker coordona Direcția „Propagandă și Agitație” a C.C. și organizațiile de femei). ${ }^{8} \mathrm{Cu}$ prilejul Congresului II al PMR din decembrie 1955, Iosif Chișinevschi (ca membru al Secretariatului C.C. până în iulie 1957, când a fost exclus ca „,antipartinic”) coordona și Secția de Relații Externe (care se ocupa de legăturile cu partidele „frățești”) și Secția Cadrelor din Exterior a CC al PMR. În martie 1965, la moartea lui Gheorghiu-Dej, Leonte Răutu (nume inițial Oigenstein) conducea Secția de Relații Externe în cadrul Secretariatului C.C. Șefã a Secției Relații Externe a CC al PMR în anii 1956-1965 a fost Ghizela Vass (născută în 1912 la Iași, membră a PCdR din 1933), numită în noiembrie 1965 șefă a Secției Internaționale a CC al PCR (în timp ce Vasile Vlad, născut în 1929, jurist, membru de partid din 1957, a preluat conducerea Secției Relațiilor Externe a C.C. în noiembrie 1965), iar între 1975-februarie 1982 G. Vass a deținut poziția de șef adjunct al Secției Relații externe și cooperare economică

\footnotetext{
${ }^{6}$ Aurel Preda-Mătăsaru, Aspecte teoretice, practice și diplomatice românești în domeniul tratatelor politice, București, Ed. „Lumina Lex”, 2007, p. 14.

${ }^{7}$ Nicoleta Ionescu-Gură, Studiu introductiv la lucrarea „Membrii C.C. al P.C.R. (19451989). Dicționar", apărută sub egida CNSAS, București, Ed. Enciclopedică, 2004, pp. 12, 22-23.

${ }^{8}$ Mihaela Verzea, Partidul-Stat. Structuri politice (1948-1965), Târgoviște, Ed. „Cetatea de Scaun”, 2013, p. 88.
} 
internațională a Comitetului Central al PCR. Este sugestivă o afirmație a fostului ministru de externe Corneliu Mănescu despre raportul dintre Secția de Relaţii Externe a CC al PMR și MAE la momentul instalării sale în fruntea ministerului în 1961. Acesta relata că Avram Bunaciu (ministru de Externe în anii 1958-1961), ,în cea mai mare parte lipsea de la lucru", Aurel Mălnășan (ministru adjunct de Externe în anii 1956-1963) fiind cel care reprezenta MAE în relația cu Ghizela Vass, în minister „de altfel, toți erau subalternii ei”’. În 1950 se înființa și o Secție a Cadrelor de Partid din Exterior (în subordinea CC al PMR și sub conducerea la acea data a Melitei Apostol, născută cu numele Schaerf, soția liderului comunist Gheorghe Apostol). Conform Regulamentului de funcționare a Secției Cadrelor din Exterior a CC al PMR din 23 aprilie 1956, aceasta, printre altele, „verifică și selecționează cadrele din nomenclatura CC al PMR pentru oficiile diplomatice, consulare, agențiile comerciale, precum și delegațiile propuse" de Ministerul Afacerilor Externe și Ministerul Comerțului Exterior și le supune spre aprobare [...]. Controlează activitatea direcțiilor de Cadre MAE și MCE în domeniul selecționării și verificării cadrelor propuse pentru muncă în străinătate. Verifică și selecționează, împreună cu Secția Administrativă, cadrele propuse de Ministerul Forțelor Armate pentru misiuni permanente de atașați militari pe lângă oficiile diplomatice ale RPR din străinătate și le supune spre aprobare. [...] Ține evidența tuturor cadrelor trimise de MAE, MCE și alte instituții pentru muncă în cadrul oficiilor diplomatice și consulare, agențiilor comerciale, misiunilor militare și altor misiuni permanente sau temporare ale RPR în străinătate [...], precum și a acelor cadre din MAE şi MCE care au perspective [subl. ns.] de a fi folosite pentru misiuni în străinătate. [...] Controlează pregătirea cadrelor din Institutul de Relații Internaționale, cât și cum se face repartizarea lor. De asemenea, controlează felul cum sunt repartizate și promovate cadrele trimise cu misiuni permanente în străinătate [subl. ns]. Pentru aceasta, secția va folosi legătura directă cu conducerea ministerelor respective, direcțiile de cadre din aceste ministere, precum și cu Institutul de Relaţii Internaționale al MAE. [...] Organizează și asigură controlul și îndrumarea activității grupelor de partid din oficiile diplomatice și agențiile comerciale ale RPR din străinătate." ${ }^{10}$ Un moment important al evoluției pe plan internațional a PMR 1-a constituit prezentarea așa-zisei "Declarații de independență"11 a Partidului

\footnotetext{
${ }^{9}$ Convorbiri neterminate. Corneliu Mănescu în dialog cu Lavinia Betea, Iași, Ed. Polirom, 2001, pp. 79-80.

10 Apud, Nicoleta Ionescu-Gură, Nomenclatura Comitetului Central al Partidului Muncitoresc Român, București, Ed. Humanitas, 2006, pp. 360-361.

11 Este vorba de Declarația cu privire la poziția Partidului Muncitoresc Român în problemele mişcării comuniste și muncitorești internaționale, adoptată de Plenara lărgită a CC al PMR din 15-22 aprilie 1964. Pregătirea propriu-zisă a Declarației a durat mai bine de
} 
Muncitoresc Român din aprilie 1964. În legătură cu efectul acesteia chiar și asupra diplomației militare a României de atunci, notăm precizarea col. (r) Emil Burghelea, atașat militar al RPR în Italia în 1963-1965: „Mulți dintre veteranii atașaturii noastre militare, aflați la posturi în 1964, își amintesc probabil impactul benefic în activitatea lor, produs de documentul conducerii de partid și de stat de atunci. (...) am simțit din plin efectul miraculos al declarației. $\mathrm{Cu} 180^{\circ} \mathrm{s}$-a schimbat atitudinea autorităților militare italiene față de mine.Ca prin farmec, au dispărut restricțiile în deplasările pe teritoriul țării de acreditare (...). Nu aveam același regim cu cel al diplomaților militari din țările membre NATO, dar eram invitat de aceștia la întâlniri bilaterale sau mondene (...)."12.

Ministerul Afacerilor Externe avea o serie de atribuții, pe care le găsim menționate într-un Regulament de funcționare a MAE din perioada R.P.R. (23 septembrie 1959) şi un Decret din 21 august 1969 privind organizarea și funcționarea MAE (decretul nr. 589/ 1969 ${ }^{13}$, devenit Legea nr. 38/ 1969, care înlocuia H.C.M. nr 113/1959). Decretul din 1969 menționa că MAE înfăptuia politica externă sub conducerea Comitetului Central al Partidului Comunist Român și a Consiliului de Miniștri, colaborând cu celelalte ministere și organe centrale. Informa conducerea PCR și Consiliul de Miniștri cu privire la evenimentele internaționale și prezenta propuneri în legătură cu acestea, asigura înfăptuirea politicii externe a statului în relațiile cu O.N.U., instituțiile sale specializate și cu alte organizații internaționale, contribuia la înfăptuirea politicii R.S.R. în domeniul relațiilor economice cu alte state, coordona activitatea privind schimburile culturale, științifice, artistice și de presă ale României cu alte state ș.a. Păstra sigiliul de Stat al R.S.R. și originalele tuturor înțelegerilor internaționale bilaterale. Miniștrii de Externe ai României în anii comunismului au fost: Ana Pauker (06.11.194726.06.1952, prima femeie ministru de externe din lume, membră a Biroului Politic al C.C. în 1945-1952, viceprim-ministru în 1949-1952), Simion Bughici (26.06.195203.10.1955), Grigore Preoteasa (03.10.1955-13.07.1957), Ion Gheorghe Maurer (13.07.1957-10.01.1958), Avram Bunaciu (17.01.1958-21.03.1961, ministru de Justiție în 1948-1949, prim-adjunct al ministrului de Externe în 1950-1952), Corneliu Mănescu (21.03.1961-18.10.1972, președinte al Adunării Generale a ONU din 1967-1968, șeful Direcției Politice din MAE în 1960, ambasador la Budapesta în 1960-1961), George Macovescu (18.10.1972-23.03.1978), Ștefan Andrei

un an de zile, între martie 1963- aprilie 1964. (Constantin Moraru, Politica externă a României. 1958 -1964, București, Ed. Enciclopedică, 2008, p. 181)

${ }^{12}$ Diplomația română a apărării. Un secol și jumătate sub zodia Minervei, coord: gen. brig. (r) ing. Mitică Detot, București, Ed. Medro, 2007, pp. 143-144.

${ }^{13}$ Arhiva M.A.E., Organizarea și funcționarea Ministerului Afacerilor Externe, București, 1971. 
(23.03.1978-08.11.1985, membru C.P.Ex. al CC al PCR în 1974-1989), Ilie Văduva (08.11.1985-26.08.1986), Ioan Totu (26.08.1986-03.11.1989), Ion Stoian (03.1122.12.1989). Dintre toți miniștrii de externe, singurii care au avut anterior în MAE o activitate mai lungă și cu funcții importante au fost Grigore Preoteasa și George Macovescu. Gr. Preoteasa, născut în 1915, cu studii la Facultatea de Litere și Filosofie, membru PCdR din 1937, deținut politic în anii '30, decedat într-un accident de avion în noiembrie 1957). A fost numit secretar general al ministerului la 14 nov. 1947, ministru-consilier la Legația României din Washington (1948), ministru adjunct şi prim-adjunct al ministrului (1949-1955). G. Macovescu, născut în 1913, absolvent al Facultății de Drept, membru PCdR din 1936, secretar general la Ministerul Propagandei/ Informațiilor în 1945-1947, însărcinat cu afaceri și consilier la Legația României din Londra (nov.1947 - 1949), director în MAE (19491952), ministru plenipotențiar la Washington (1959-1961), ministru adjunct și primadjunct al ministrului (1961-1972). ${ }^{14}$

Colaborarea la oficiile diplomatice ale României între reprezentanții MAE și cei ai Ministerului Comerțului Exterior, Ministerului Apărării Naționale și Ministerului de Interne se realiza pe baza unor decizii ale conducerii PCR în acest sens, precum Hotărârea privind reglementarea raporturilor între șefii oficiilor diplomatice și lucrătorii M.C.E., M.F.A. și M.A.I. în străinătate din octombrie 1955. Aceasta preciza, printre altele: „Pentru asigurarea activității normale a oficiilor diplomatice ale RPR, cât şi în vederea întăririi disciplinei de muncă a lucrătorilor diferitelor departamente de stat cu misiuni în străinătate, Biroul Politic al Partidului Muncitoresc Român hotărăște: Șeful oficiului diplomatic reprezintă statul și guvernul român în străinătate. Șeful oficiului diplomatic este șeful întregului personal român numit în străinătate şi poartă răspunderea pentru activitatea și comportarea tuturor funcționarilor statului român care îndeplinesc misiuni temporare sau permanente în cadrul sau pe lângă oficiul diplomatic al RPR în țara respectivă. (...) Șeful oficiului diplomatic este dator: să creeze lucrătorilor MAI, care muncesc în cadrul oficiului diplomatic respectiv, condițiuni favorabile de acoperire, spațiul corespunzător pentru muncă și tot timpul necesar, ca să-și poată desfășura activitatea și îndeplini sarcinile; să țină legătura directă pe linia muncii speciale MAI numai cu șeful serviciului respectiv, deși va cunoaște nominal, în interesul bunei desfășurări a muncii lor, pe toți subalternii acestuia în cadrul oficiului diplomatic respectiv. (...); să atragă atenția șefului serviciului MAI, iar la nevoie să sesizeze pe Ministrul Afacerilor Externe personal asupra aspectelor ce le consideră nepotrivite din activitatea lucrătorilor MAI. Lucrătorii MAI din cadrul oficiului

\footnotetext{
${ }^{14}$ Stelian Neagoe, Miniștrii de Externe ai României. 1862-2016, București, Ed. Institutului de Științe Politice și Relații Internaționale „Ion I.C. Brătianu”, 2016, pp. 286, 303.
} 
diplomatic sunt datori: (...), să muncească efectiv 3-4 ore pe zi pentru îndeplinirea sarcinilor primite de la șeful oficiului diplomatic în cadrul muncii lor de acoperire și să răspundă de executarea acestor sarcini, urmând ca restul orelor din program să le folosească pentru munca lor de bază ${ }^{15}$ pe linia MAI. Timpul muncii de acoperire se va repartiza în așa fel ca să nu dăuneze muncii lor operative; să nu lipsească de la serviciu în cadrul oficiului fără știrea și aprobarea șefului oficiului. (...); șeful oficiului diplomatic nu va cere informații asupra muncii operative secrete a lucrătorilor MAI (...) Numărul de locuri necesare pentru MAE, MCE, MFA și MAI, în schema fiecărui oficiu diplomatic, consular sau comercial se stabilește de către conducerea Partidului Muncitoresc Român. Ministrul Afacerilor Externe, Ministrul Comerțului Exterior, Ministrul Forțelor Armate și Ministrul Afacerilor Interne vor raporta periodic Biroului Politic al Partidului Muncitoresc Român asupra executării prezentei Hotărâri (...)." ${ }^{\prime 16}$ Potrivit unui document din 1956, printre atribuțiile Direcției Informații Politice Externe a Securității, erau și stabilirea planurilor politice și intențiile țărilor capitaliste împotriva RPR și a altor țări de democrație populară, cunoașterea situației politice și economice în țările capitaliste și

\footnotetext{
${ }^{15}$ Potrivit șefului spionajului francez din anii 1970-1981, Alexandre de Marenches, într-o ambasadă din Europa de Est de obicei o jumătate sau o treime din personal aparținea serviciilor speciale, agenții deținând în ambasade, consulate, firme de import-export „, pondere enormă", spre deosebire de țările occidentale (Christine Ockrent, contele de Marenches, Consilier de taină al Puterii, traducere după Ed. Stock /Paris, 1986/, București, Ed. Humanitas, 1992, p. 117. Este relevant faptul că în 1971 Marea Britanie a expulzat 105 diplomați sovietici.

${ }^{16}$ A.N.I.C., fond CC al PCR/ Secția Administrativ - Politică, dosar nr. 17/ 1955. În martie 1969 Prezidiul Permanent al CC al PCR adopta un document asemănător, intitulat Hotărâre privind colaborarea dintre MAE, MCE, MFA și celelalte organe centrale, care desfăşsoară activitatea de relații externe, precum și dintre șefii misiunilor diplomatice și lucrătorii acestora trimişi în misiune în străinătate. Documentul („Strict secret de importanță deosebită”) avea și o Anexă intitulată Precizări cu privire la colaborarea dintre Ministerul Afacerilor Externe, Ministerul Comerțului Exterior și alte organe centrale cu Consiliul Securității Statului și Ministerul Forțelor Armate, precum și intre șefii misiunilor diplomatice și ofițerii de informații trimiși la post în străinătate. Se menționa, printre altele, că ofițerii de informații ai CSS și cei ai MFA erau trimiși în calitate de salariați ai MAE, MCE sau ai „altor instituții și organizații”, numărul de posturi din fiecare misiune diplomatică, oficiu consular sau secție economică, necesar CSS și MFA, era aprobat de Prezidiul Permanent al CC al PCR la propunerea conducătorilor celor două instituții, după o consultare prealabilă a ministrului de Externe și a ministrului Comerțului Exterior, iar șeful colectivelor de ofițeri era dator să informeze verbal ,în mod operativ" pe șeful misiunilor diplomatice cu date de interes culese prin mijloace speciale despre țara în care activau, „,necesare pentru orientarea activității misiunii diplomatice”, însă acestea nu se transmiteau către MAE sau MCE ,spre a evita paralelismul și suprapunerea în sistemul de informare, precum și mărirea artificială a volumului de muncă" (Arhiva C.N.S.A.S., fond Documentar, dosar nr. 3447, vol. 35, ff. 284, 295-299.)
} 
„contradicțiile din lagărul imperialiștilor" ${ }^{17}$, datele ajungând la decidenții politici. În cadrul organizației Tratatului de la Varşovia, înființată în mai 1955 de către U.R.S.S., România, R.D. Germană, Ungaria, Cehoslovacia, Polonia, Bulgaria și Albania (care va ieși oficial din organizație în 1968, dar în fapt din 1961) ca o contrapondere la NATO, exista oficial un Comitet al Miniștrilor Afacerilor Externe, constituit ca urmare a deciziei luate în cadrul Consfătuirii Comitetului Politic Consultativ de la București din 25-26 noiembrie 1976. Era un organ auxiliar al structurii supreme de conducere a Tratatului de la Varșovia, cu atribuții de efectuare periodică de schimburi de păreri şi de elaborare de recomandări asupra problemelor externe stabilite de acesta. Acest Comitet se întrunea de regulă o dată pe an sau când situația o impunea. Până la înființarea sa, miniștrii Afacerilor Externe ai statelor participante la Tratat (O.T.V.) s-au întâlnit de nouă ori, iar adjuncții acestora, de trei ori $^{18}$. Problemele care urmau a fi dezbătute de către Comitetul Politic Consultativ (organul suprem al Tratatului de la Varșovia) erau cunoscute din timp, la elaborarea documentelor participând un colectiv din fiecare țară, condus, de regulă, de un adjunct al ministrului de Externe. În cazul României, la această activitate pregătitoare luau parte efectiv conducerile M.A.E. și M.Ap.N. Exista, de altfel, și un Secretariat Unit al Tratatului de la Varşovia, care avea ca atribuții, în principal, pregătirea tehnico-organizatorică și deservirea lucrărilor Comitetului Politic Consultativ (C.P.C.) și a ședințelor Comitetului Miniştrilor Afacerilor Externe, fiind condus pe o perioadă determinată de către un ministru adjunct de Externe al unei țări membre a Tratatului, stabilit nominal de către C.P.C. al O.T.V.

La momentul de vârf al politicii externe a României comuniste, în 19731974, țara noastră avea relații diplomatice și consulare cu 118 state (față de 25 de state în 1947), era membră în 16 organizații internaționale din sistemul ONU și încheiase după 30 decembrie 1947 peste 3.500 de tratate, acorduri, convenții și alte

17 C.N.S.A.S, Securitatea. Structuri, cadre, obiective și metode, vol. 1, București, Ed. Enciclopedică, 2006, p. 140.

${ }^{18}$ Gen. col. (r) C. Olteanu, col. (r) dr. Al. Duțu, gen. mr. (r) C. Antip, România și Tratatul de la Varșovia, București, Ed. Pro Historia, 2005, p. 23. Ca fapt divers, delegația guvernamentală română care a participat la 11-14 mai 1955 la crearea Tratatului de la Varșovia era compusă din: Gh. Gheorghiu-Dej (președinte al Consiliului de Miniștri), gen. Emil Bodnăraș (ministrul Forțelor Armate), gen. Ion Tutoveanu (prim-adjunct la conducerea MFA și șef al Marelui Stat Major), Simion Bughici (nume iniţial David Simon, ministrul Afacerilor Externe), Grigore Preoteasa (prim-adjunct al ministrului de Externe), iar ca experți: Silviu Brucan (nume inițial Saul Bruckner, redactor-șef adjunct al ziarului Scânteia, numit ministru plenipotențiar în SUA în martie 1956) și Radu Comşa (nume inițial Leo Schwefel, fost secretar al Anei Pauker la MAE, în 1990-1992 a fost ambasador în RFG). (op.cit., p. 131) 
înțelegeri internaționale ${ }^{19}$, dintre care 482 de acorduri cu caracter multilateral (care cuprind și 156 de convenții și protocoale referitoare la colaborarea în cadrul CAER) şi 3.062 acorduri cu caracter bilateral (care cuprind și 48 de acorduri în domeniul financiar-bancar cu țări capitaliste și 35 de acorduri financiar-bancare cu țări socialiste sau 8 acorduri privind turismul cu țări socialiste față de 6 astfel de acorduri cu țări capitaliste). ${ }^{20}$ Dintre instrumentele internaționale multilaterale la care România devenise parte după 1948, menționăm convențiile privind privilegiile și imunitățile diplomatice și consulare (8 convenții), drepturile omului (29), ocrotirea sănătății (9), protecția victimelor în caz de conflict armat, protecția drepturilor intelectuale și industriale, cooperarea în domeniul educaţiei, ştiinței şi culturii (15), transporturile internaționale (68), dreptul mării, pescuitul oceanic, maritim și fluvial, cele privind responsabilitatea în caz de poluare a mărilor și oceanelor, cele privind produsele de bază și protecția plantelor, cele de comerț, vamale și de arbitraj comercial internațional, telecomunicații internaționale (46) sau Tratate privind unele măsuri de limitare a cursei înarmărilor (6) și 2 Tratate privind salvarea astronauților și răspunderea pentru obiectele lansate în cosmos. Numai între 1970-1973 relațiile economice ale României cu țările în curs de dezvoltare au crescut de circa 7 ori, reprezentând la începutul anului 1974 aproape 10\% din totalul schimburilor comerciale românești. În legătură cu situaţia MAE de la începutul anilor '70, ambasadorul Valentin Lipatti își amintea că în 1972 MAE avea „un aparat diplomatic și administrativ pletoric, un parc de mașini foarte mare, cantină și policlinică proprie și multe alte înlesniri." ${ }^{21}$ Situația aceasta s-a schimbat după 1975, când Securitatea și CC al PCR au preluat tot mai mult controlul asupra MAE. Ion Pătrașcu își amintea că ,în perioada anilor 1979-1989, când am îndeplinit funcția de șef de cabinet al ministrului secretar de stat al MAE, care se ocupa în mare măsură şi de problemele de personal, m-am putut convinge că Odiseea diplomaților români era departe de a se fi terminat. Au fost vremurile grele când s-au făcut numeroase transferări din minister, pe baza unor indicații și liste primite din altă parte. [subl. ns.](...) Au fost puține, foarte puține cazurile de salvare a unor diplomați de la

19 MAE colabora cu diverse instituții pe plan extern, dar și intern, precum Ministerul Comerțului Exterior, Ministerul de Interne (probleme consulare, acordarea vizelor și avizelor etc), Ministerul Apărării Naționale (vezi Tratatul de la Varșovia, cel al delimitării topografice a granițelor, existând și o Secție a Fruntariilor în MAE până în 1952), Agerpres (care trimitea corespondenți permanenți în străinătate și colabora cu Direcția Presei din MAE), BNR și Ministerul Finanțelor (despăgubiri pentru naționalizările din 1948, relația cu FMI, BIRD ș.a.), Ministerul Învățământului (burse doctorale, cursuri postuniversitare de R.I.), birouri Navrom, Tarom și ONT din exterior ș.a.

${ }^{20}$ N. Ecobescu, S. Celac, Principiile politicii externe a României socialiste, Ed. Politică, 1974, pp. 21-28.

${ }^{21}$ Valentin Lipatti, Strada Povernei 23. Memorii, București, Ed. Garamond, 1993, p. 193. 
deciziile respective." 22 De asemenea, diplomatul Stelian Oancea ( secretar de stat la MAE în anul 2000, şef de cabinet în 1969-1971 al lui G. Macovescu, atunci primadjunct al ministrului de Externe) sublinia în memoriile sale că „lui George Macovescu i-au fost luate din mâini, treptat, frâiele ministerului (o spune tot Ștefan Andrei în cartea abia menţionată: Ministerul de Externe era transformat într-o anexă a Secției de Relații Externe a CC al PCR). Cei ce i-au urmat în funcție lui Mac [Macovescu - n.n.] nu au < simțit> Ministerul de Externe ca aparținându-le și nu sau simțit aparținându-i [...], nu au avut mândria de $<$ a fi diplomat $>$. Nici nu erau! [...] În ministeriatul lui Ștefan Andrei, procesul de <rotare a cadrelor> ajunsese la viteza de croazieră și se desfăşura din plin: diplomații de carieră, specialiștii cu experiență, unii dintre ei adevărate personalități, erau trimiși să lucreze la ADAS, la CEC, la Turism, la Cooperație ori în fabrici și uzine. Golul lăsat de ei era urgent umplut cu alți oameni, în majoritatea lor din Servicii. [...] în ministerul lui Corneliu Mănescu reprezentanții altor agenții naționale, când reveneau în țară de la posturile ocupate în ambasade, se întorceau în instituțiile lor de origine. Ștefan Andrei a admis ca Ministerul de Externe să nu mai aibă identitate distinctă și ca serviciile [Securitatea - n.n.] să-și mute parte din activitate aici." ${ }^{23}$ Constantin Ene (angajat al MAE între 1956-2005, secretar de stat în 1990-1993) ținea să precizeze că ,în România acelor ani existau multe structuri guvernamentale (sau de partid) dispuse să-și aroge competențe în politica externă și chiar să legifereze. [...] Pe fondul de mai sus, apăreau adeseori și factori perturbatori. Unul dintre aceștia erau structurile de partid separate de cele guvernamentale. Ca regulă, în relațiile cu conducerea statului prevalau, fiind vorba de politica externă, considerațiile de stat. Interveneau însă, uneori <strâmbe>, în special din partea Secției de relații externe de la partid, în legătură cu abordările ministerului [...] Diplomația și politica nu aveau cum face casă bună împreună. [...] Un alt factor perturbator era multitudinea structurilor de relații externe, departamente și servicii. Unul dintre ele, Departamentul Securității (serviciul de informaţii externe), era chiar mai bine echipat decât Ministerul de Externe. Acestea urmăreau pe cont propriu problemele internaţionale, elaborau propriile lor analize și le înaintau conducerii statului. Ceaușescu accepta sistemul pentru că îi dădea posibilitatea ca, atunci când primea mai multe puncte de vedere, să-și impună opțiunile. Sistemul genera însă confuzii."24

\footnotetext{
${ }^{22}$ Ion Pătrașcu, Peregrinările unui diplomat, București, Editura „Victor”, 2008, pp. 145-146. ${ }^{23}$ Stelian Oancea, Cheia rămâne la Paris: memorii, vol. 1, Iași, Ed. Junimea, 2014, pp. 307 308.

${ }^{24}$ Constantin Ene, Diplomat în anii comunismului, în „Pagini din diplomația României”, vol. 3, Iași, Ed. Junimea, 2011, pp. 25-27. Acesta oferă în continuare un exemplu din 1989 din care reiese că DSS intervenea și în privința poziției delegației române la o Conferință internațională: „Era începutul anului 1989 și în discuție se afla un document care se
} 
Concluzionând, Ministerul de Externe a deținut efectiv un loc important în sistemul instituțional al României comuniste în timpul guvernului condus de I.Gh. Maurer în 1961-1974.

negociase la o reuniune a C.S.C.E., la Viena, pe tema drepturilor omului. Documentul conţinea câteva paragrafe care făceau referiri critice la politicile guvernului român și propunea, printre altele, trimiterea la București a unor experți care să se informeze asupra situației. [...] Întorcându-mă la minister, am aflat însă că documentul fusese pus la vot în timp ce noi eram la Ceaușescu și delegația română votase împotrivă (în acele timpuri, în chestiuni care priveau cazuri de violare a drepturilor omului în România, avizul final era dat de Departamentul Securității).” Diplomatul C. Ene consideră că după venirea lui C. Mănescu în fruntea ministerului în 1961, „Ministerul Afacerilor Externe a început să fie parte la deciziile importante care se luau în materie de politică externă. Era consultat, i se cerea avizul, formula observații. [...] aproape fără excepție, mandatul și directivele delegațiilor române la cele mai importante conferințe și dezbateri internaţionale erau elaborate de M.A.E. (în multe cazuri și pentru partea de politică externă a reuniunilor Tratatului de la Varșovia, deși acest for ținea de organele de partid)" (Ibidem, p. 21) 